\author{
V.M. Yurov, S.A. Guchenko, V.Ch. Laurinas, O.N. Zavatskaya \\ Ye.A. Buketov Karaganda State University, Kazakhstan \\ (E-mail: exciton@list.ru)
}

\title{
Structural phase transition in surface layer of metals
}

\begin{abstract}
In the article a review of various phenomena on the surface of pure metals is given: the occurrence of the surface states of Tamm and Shockley; quantum size effects; electric double layer, the work function of electrons from a metal. According to modern concepts, the surface layer is a very thin phase that is in thermodynamic equilibrium with volume. A new model of the surface layer of metals has been proposed. The main attention is paid to the structural phase transition in the surface layer. This question is raised by us for the first time. In order to describe phase transitions in nanostructures, various models have been proposed, among which we can mention the Landau mean field method, in which the order parameter is used. We will use the Landau theory, replacing the temperature $\mathrm{T}$ with the coordinate $\mathrm{h}$. It was experimentally shown that the heat capacity jumps $\Delta \mathrm{Cp}=0, \mathrm{~d}=1.15(\mathrm{~J} / \mathrm{mol} \cdot \mathrm{K})$. The molecular dynamics calculations for the heat capacity of gold with particle sizes from 1.5 to $5.5 \mathrm{~nm}$ showed that $\Delta \mathrm{Cp} \approx 1.65(\mathrm{~J} / \mathrm{mol} \cdot \mathrm{K})$. This is close to our result, given the proximity of computer calculations. The lattice parameter of gold is a $=0.4 \mathrm{~nm}$. So the $\mathrm{d}$ (I) layer contains about 3 monolayers of atoms of gold and d (II) - about 6 monolayers of gold.
\end{abstract}

Keywords: surface layer, nanostructure, phase transition, Landau theory, heat capacity.

\section{Introduction}

The study of the physical properties of various substances shows that these properties substantially depend on the size of the sample, starting from its certain critical value. This is explained by the difference in the properties of substances in the local near-surface layers and in the bulk. With a decrease in the sample size (for example, film thickness), the contribution of the surface layers to the total sample characteristic increases and the averaged characteristics of the substance change. This phenomenon is called a size effect and is fundamental in the nanoworld (nanophysics, nanochemistry, nanogeology, etc.) [1-10].

According to modern concepts, the surface layer is a very thin phase that is in thermodynamic equilibrium with volume [11]. Regarding the thickness of the surface layer, there are various approaches. Thus, in [12], the concept of a natural surface layer of a metal is introduced, which differs from the main volume of the metal by mechanical, physical, and sometimes chemical properties. Large stresses occur in this layer due to the following technological operations:

- heat treatment (for example, quenching, tempering, annealing);

- chemical treatment (for example, carbonization, nitriding);

- electrochemical treatment (for example, electrolytic coating);

- physical treatment (for example, ion implantation).

The study of such surface layers, the main characteristic of which is the surface roughness, led to the creation of a scientific direction - surface engineering [13-15]. This branch of knowledge pays special attention to the issues of metal corrosion, tribology, the processes of material wear and destruction. Let's call this metal layer a technological layer the thickness of which can range from fractions to hundreds of microns.

When splitting single crystals in vacuum, three types of surfaces can form along the cleavage plane: singular (atomically smooth), vicinal (stepped), non-singular (diffuse) surfaces (Fig. 1) [16-18]. The study of such surfaces became possible after the development of ultrahigh-vacuum technology, atomic force and tunneling spectroscopy [19-22].
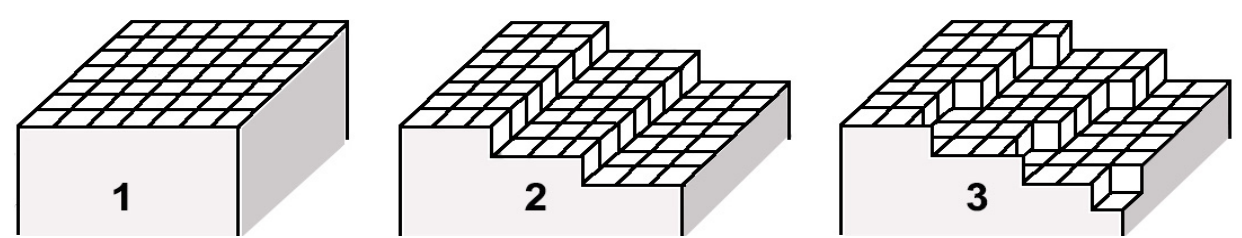

1 - singular (atomic-smooth); 2 - vicinal (stepped); 3 - non-singular (diffuse) surfaces

Figure 1. Three types of surfaces 
We will consider mainly atomic-smooth surfaces, although we will illuminate some moments of other types of surfaces [23-31].

This paper provides an overview of various phenomena on the surface of pure metals. A new model of the surface layer of metals has been proposed. The main attention is paid to the structural phase transition in the surface layer. This question is raised by us for the first time.

\section{Surface levels in metals}

As early as 1932, I.E. Tamm [32] predicted the existence of surface levels, which subsequently received his name. Later, Tamm levels were experimentally detected on an atomically clean surface of germanium.

The surface Tamm levels are due to the fact that the potential barrier of a surface atom differs from the potential barrier of a deep-seated atom (Fig. 2). The solution of the Schrödinger equation for surface strongly and weakly bound electrons leads to the conclusion that, in addition to the usual energy bands, there are surface energy states of electrons. The concentration of such levels is proportional to the surface concentration of atoms and can reach $1019 \mathrm{~m}-3$. With such a high concentration of Tamm levels, their splitting into the energy zone is possible.

The Shockley surface levels [33] are formed as a result of the breaking of a part of the chemical bonds of surface atoms. Uncompensated valence bonds are capable of accepting and fixing charge carriers.

An analysis of the Shockley model as applied to a one-dimensional atomic chain showed that two energy levels are formed in the forbidden band, one of which differs from the valence band and the other from the conduction band. Shockley levels, like the Tamm levels, can exist only on an ideal surface.

Sources of surface states can also be:

- adsorbed foreign atoms, both donors and acceptors;

- steps, dislocations, mechanical stresses;

- the distribution of its own metal atoms or semiconductor in the surface layer, which is different from the bulk one;

- boundaries between uniformly oriented domains on the surface.

Usually, as a result of the joint action of these sources, the density of surface states is less than that of Tamm.

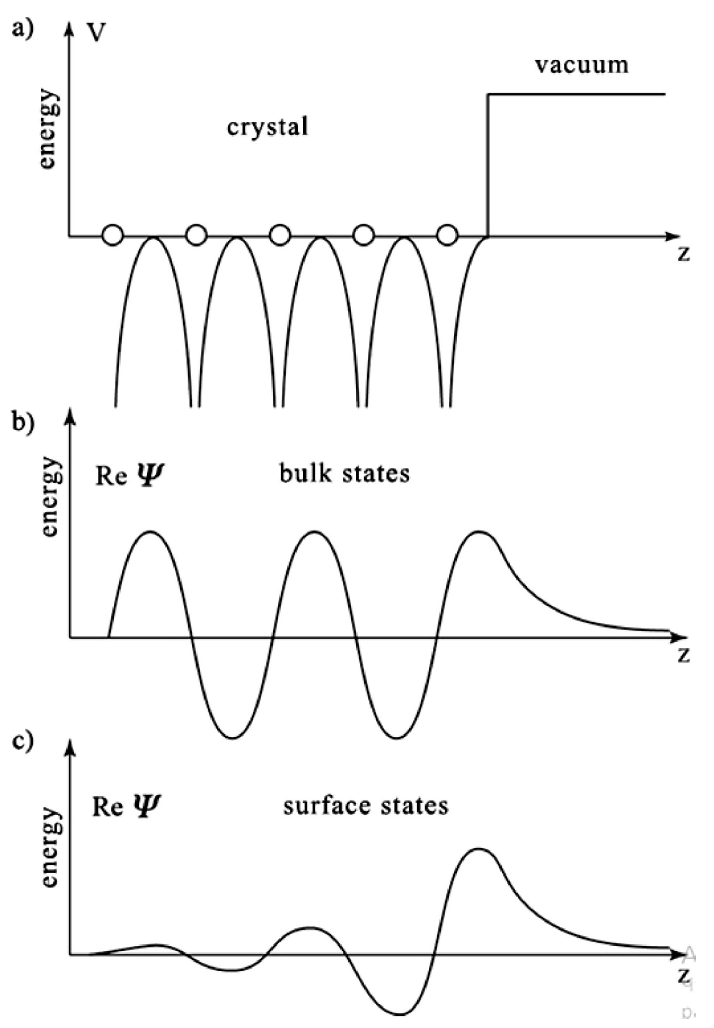

Figure 2. Potential crystal relief (a), bulk (b) and surface (c) states 


\section{Quantum-size effects in metals}

Quantum-dimensional structures [34, 35], in which only one quantum level is filled, are called twodimensional electronic structures. If the movement of carriers is limited not in one, but in two directions, then in this case the carriers can move freely only in one direction, along the thread. In the cross section (the yz plane) the energy is quantized and takes discrete values of $\mathrm{E}_{\mathrm{mn}}$ (like any two-dimensional motion, it is described by two quantum numbers, $m$ and $n$ ). The full spectrum is also discretely continuous, but with only one continuous degree of freedom:

$$
E=E_{m n}+\frac{p_{x}^{2}}{2 m} .
$$

By analogy with film structures having a spectrum (1), these systems are called one-dimensional electronic structures or quantum filaments.

Finally, there are structures resembling artificial atoms, where motion is restricted in all three directions. Here the energy spectrum no longer contains a continuous component, but is purely discrete. As in the atom it is described by three discrete quantum numbers (not counting the spin) and can be written as $\mathrm{E}=\mathrm{E}_{\mathrm{lmn}}$, and, as in the atom, the energy levels can be degenerate. Such systems are called zerodimensional electronic structures or quantum dots.

In order for quantization of the energy spectrum to manifest itself in any observable effects, the distance between the energy levels $E_{n+1}-E_{n}$ must be sufficiently large. First of all, it should significantly exceed the thermal energy of the carriers:

$$
E_{n+1}-E_{n}>k T
$$

otherwise, the almost identical population of neighboring levels and frequent carrier transitions between them make quantum effects unobservable.

If the electron gas is degenerated and characterized by the Fermi energy $\mathrm{E}_{\mathrm{F}}$, then in order to observe quantum-size effects, the condition:

$$
E_{n+1}-E_{n} \geq E_{F} .
$$

In accordance with requirement (3), metal structures are not very suitable for observing quantum size effects, since EF in typical metals is several electron volts, which is known to be greater than any distance between levels. Semiconductor or semimetallic structures are clearly preferable here.

\section{Metal surface reconstruction and relaxation}

Consider the atomic structure of the surface of the sample, formed as a result of cleavage along a certain crystallographic plane. Due to the fact that there are no atoms on one side, the nature of the interatomic forces on the surface should change. As a result, the equilibrium structure of the upper atomic layer must differ from the corresponding atomic plane in the bulk. There are two main types of atomic surface rearrangement [16-18]: relaxation; reconstruction.

The surface relaxation is understood as the difference between the distances between the last crystallographic planes parallel to the plane of the boundary with vacuum, and the distances between the same planes in the bulk. It is assumed that the arrangement of atoms in the last plane completely coincides with the arrangement of atoms in all other planes parallel to it.

In turn, the relaxation is subdivided into normal and lateral (the latter is also called parallel or tangential). Normal relaxation corresponds to the case when the atomic structure of the upper layer is the same as in the volume, but the distance between the upper and second layer differs from the distance between the planes in the volume. In its pure form, normal relaxation is observed in metals.

With rare exceptions, the surface of most metals is unreconstructed and subject to relaxation. For lowindex planes, relaxation is, as a rule, purely normal. Some high index planes are characterized by a combination of normal and lateral relaxation.

The aluminum surface A1 (110) is a typical example of relaxation of a low-index metal surface.

This is a purely normal relaxation (Fig. 3a). Like most metals, the first interlayer distance $d_{12}$ is compressed [36]. The magnitude of this compression, normalized to the interlayer distance in the crystal volume, $\Delta_{12}=\left(\mathrm{d}_{12}-\mathrm{d}_{\text {bulk }}\right) / \mathrm{d}_{\text {bulk }}$, is $-8.6 \%$. In general, for face-centered and bulk-centered metals this value is in the range from zero to several tens of percent, and it is higher for surfaces with a low packing density of atoms. 


\section{Relaxation}

normal

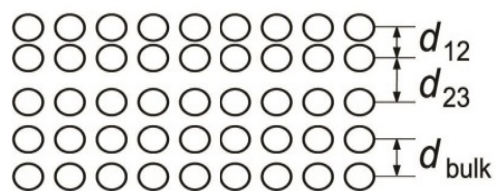

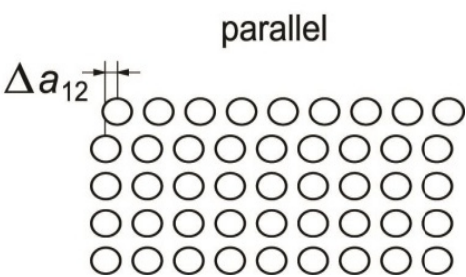

$\mathrm{b}$

Figure 3. Normal (a) and lateral (b) surface relaxation

Deviations of the interlayer distance from the bulk value decrease with depth, and often oscillatorily. In particular, in the case of the A1 (110) surface, the second interlayer distance is stretched by $+5.0 \%$, and the third is again compressed, albeit slightly, by $-1,6 \%$.

On the surfaces of some noble and semi-noble face-centered metals (for example, Au, Ir and Pt), as well as transition-centered metals ( $\mathrm{W}$ and Mo), there are reconstructions.

\section{Electric double layer in metals}

The metal surface can be escaped only by conduction electrons the energy of which is sufficient to overcome the potential barrier present on the surface $[37,38]$. The removal of an electron from the outer layer of the ions of the lattice leads to the appearance in the place that left the electron an excessive positive charge. Coulomb interaction with this charge causes an electron, the speed of which is not very large to return. As a result, the metal is surrounded by a thin cloud of electrons. Together with the outer layer of ions, this cloud forms a double electric layer. The forces acting on an electron in such a layer are directed inside the metal. The work done against these forces during the transfer of an electron from a metal to the outside, goes to increase the potential energy of the electron. Due to the fact that the thickness of the double layer coincides in order of magnitude with the size of the atom, the field strength in the layer reaches values of the order of $108 \mathrm{~V} / \mathrm{cm}$, which makes it possible to balance the gigantic internal pressure of the electron gas.

The thickness of the space charge region is determined by the concentration of free charge carriers $\mathrm{n}_{0}$ in the material: $\ell_{D} \approx 1 / \sqrt{n_{0}}$. Thus, for example, in $\mathrm{BaTiO}_{3} 1 \mathrm{D} \sim 2 \cdot 10^{-7} \mathrm{~cm}$, and the corresponding near-surface concentration of charge carriers is $\mathrm{n}_{0} \sim 5 \cdot 10^{20} \mathrm{~cm}^{-3}$. When the electron density in the metal is $\mathrm{n}_{0} \approx 10^{23} \mathrm{~cm}^{-3}$ $\ell_{\mathrm{D}} \approx 0.310^{-11} \mathrm{~cm}$. The total electron energy in the metal is composed of the potential and kinetic energies. At absolute zero, the values of the kinetic energy of the conduction electrons are in the range from zero to the energy $E_{\max }$ coinciding with the Fermi level. In Figure 4 energy levels of the conduction band are inscribed» in the potential well.

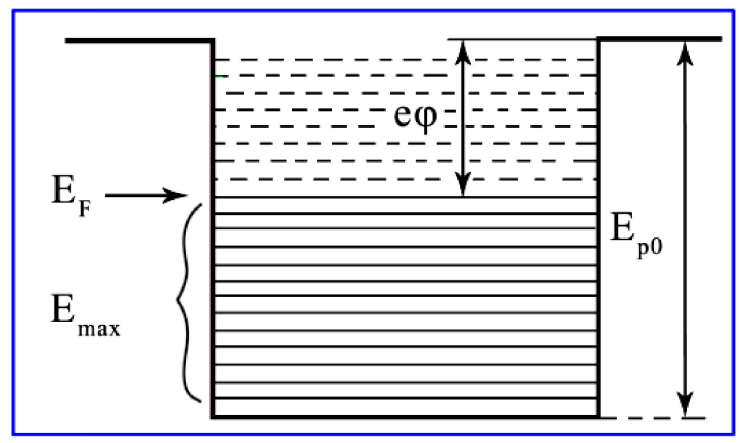

Figure 4. Diagram of the energy levels of the metal

To remove metal outside the metal, different electrons must be given dissimilar energy. Thus, an electron located at the lowest level of the conduction band must be given energy ER0; for an electron located at the Fermi level, the energy $E_{P 0}-E_{\max }=E_{P 0}-E_{F}$ is sufficient. 
The lowest energy that an electron needs to communicate in order to remove it from a solid or liquid body into a vacuum is called the work function. The work output is usually denoted by e $\varphi$, where $\varphi$ is a quantity called the output potential. The electron work function of a metal is determined by the expression:

$$
e \phi=E_{p_{0}}-E_{F} .
$$

The thickness of the surface layer of atomically smooth metals its size:

In $[39,40]$ we obtained a formula that describes the dependence of the physical property of a solid on

$$
A(h)=A_{0} \cdot\left(1-\frac{d}{h}\right),
$$

here $A_{0}$ is the physical property of the massive sample; $A(h)$ is the physical property of a small particle or thin film; $d$ is a dimensional parameter.

For the size parameter, we have obtained the formula [39, 40]:

$$
d=\frac{2 \sigma \mathrm{v}}{R T}
$$

here $\sigma$ is the surface tension of the bulk sample; $v$ is the molar volume; $R$ is the gas constant; $T$ temperature.

For $\mathrm{h} \leq \mathrm{d}$, formula (5) loses its physical meaning $(\mathrm{A}(\mathrm{h}) \rightarrow \infty)$ ), so we will define the function $\mathrm{A}(\mathrm{h})$ in this area so that at the point $\mathrm{h}=0$, the function A (h) turns to zero (Fig. 5). This condition is fulfilled when the function (2) is rewritten as:

$$
A(h)=A_{0} \cdot\left(1-\frac{d}{d+h}\right) .
$$

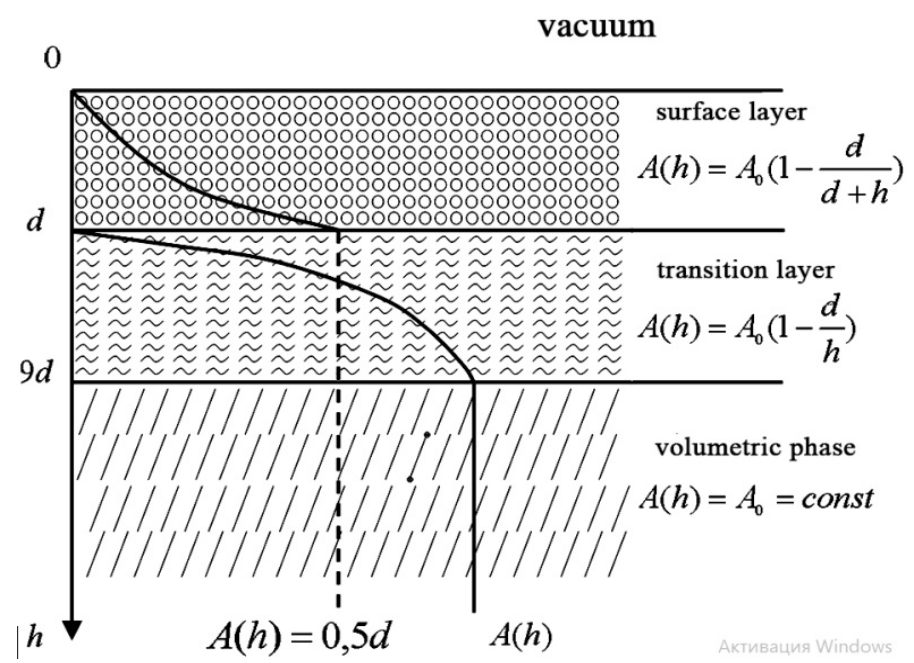

Figure 5. Schematic representation of the surface layer

The values of the parameter $\mathrm{d}$ for some metals are given in Table. The experimental value for atomically smooth surfaces of gold crystals, obtained in the geometry of sliding x-rays [41], is $2.4 \mathrm{~nm}$. This almost coincides with Table.

However, the size dependence of the physical properties of solids begins at $\mathrm{h} \approx 10 \mathrm{~d}$. We call it the thickness of the nanostructure and denote (II). 
The thickness of the surface layer (I) of some metals

\begin{tabular}{|c|c|c|c|c|c|c|c|c|c|c|c|}
\hline $\mathrm{Me}$ & $\mathrm{d}, \mathrm{nm}$ & $\mathrm{Me}$ & $\mathrm{d}, \mathrm{nm}$ & $\mathrm{Me}$ & $\mathrm{d}, \mathrm{nm}$ & $\mathrm{Me}$ & $\mathrm{d}, \mathrm{nm}$ & $\mathrm{Me}$ & $\mathrm{d}, \mathrm{nm}$ & $\mathrm{Me}$ & $\mathrm{d}, \mathrm{nm}$ \\
\hline $\mathrm{Li}$ & 0,7 & $\mathrm{Sr}$ & 5,8 & $\mathrm{Sn}$ & 1,4 & $\mathrm{Cd}$ & 1,3 & $\mathrm{Fe}$ & 2.2 & $\mathrm{Gd}$ & 5.3 \\
\hline $\mathrm{Na}$ & 1,5 & $\mathrm{Ba}$ & 6,2 & $\mathrm{~Pb}$ & 1,8 & $\mathrm{Hg}$ & 0,6 & $\mathrm{Co}$ & 2,0 & $\mathrm{~Tb}$ & 5,3 \\
\hline $\mathrm{K}$ & 2,6 & $\mathrm{Al}$ & 1,5 & $\mathrm{Se}$ & 1,3 & $\mathrm{Cr}$ & 2,7 & $\mathrm{Ni}$ & 1,9 & $\mathrm{Dy}$ & 5,3 \\
\hline $\mathrm{Rb}$ & 2,9 & $\mathrm{Ga}$ & 0,6 & $\mathrm{Te}$ & 2,5 & $\mathrm{Mo}$ & 4,6 & $\mathrm{Ce}$ & 3,8 & $\mathrm{Ho}$ & 5,5 \\
\hline $\mathrm{Cs}$ & 3,6 & $\mathrm{In}$ & 1,1 & $\mathrm{Cu}$ & 1,6 & $\mathrm{~W}$ & 5,8 & $\mathrm{Pr}$ & 4,2 & $\mathrm{Er}$ & 5,5 \\
\hline $\mathrm{Be}$ & 1,3 & $\mathrm{Tl}$ & 1,9 & $\mathrm{Ag}$ & 2,2 & $\mathrm{Mn}$ & 2,0 & $\mathrm{Nd}$ & 4,5 & $\mathrm{Tm}$ & 5,2 \\
\hline $\mathrm{Mg}$ & 2,2 & $\mathrm{Si}$ & 3,4 & $\mathrm{Au}$ & 2,3 & $\mathrm{Tc}$ & 3,6 & $\mathrm{Sm}$ & 4,4 & $\mathrm{Yb}$ & 4,6 \\
\hline $\mathrm{Ca}$ & 4,9 & $\mathrm{Ge}$ & 2,8 & $\mathrm{Zn}$ & 1,1 & $\mathrm{Re}$ & 4,6 & $\mathrm{Eu}$ & 5,8 & $\mathrm{Lu}$ & 5,7 \\
\hline
\end{tabular}

In $[39,40]$ we showed that the surface tension with high accuracy is given by:

$$
\sigma=0,7 \cdot 10^{-3} T_{m},
$$

where $T_{m}$ is the melting point $(K)$ of the bulk sample: $\sigma\left[\mathrm{J} / \mathrm{m}^{2}\right]$.

If we substitute (8) into (6) at $T=T_{m}$, we obtain that the thickness of the surface layer (I) of an atomically smooth solid is equal to:

$$
d=0,17 \cdot 10^{-3} \cdot \mathrm{v}
$$

For gold, $v=10.21\left(\mathrm{~cm}^{3} / \mathrm{mol}\right)=10.2110^{-6}\left(\mathrm{~m}^{3} / \mathrm{mol}\right)$; $\mathrm{d}(\mathrm{Au})=1.74 \mathrm{~nm}\left(\right.$ at $\left.\mathrm{T}_{\mathrm{m}}=1337 \mathrm{~K}\right)$. From the dependence $d_{300}=T_{m} / d(A u) \cdot T_{300}$ follows: $d_{300}=2.23 \mathrm{~nm}$. This value is slightly (3\%) different from the value given in Table.

\section{Orientational phase transition and Landau theory}

It follows from Figure 5 that at $\mathrm{h}=\mathrm{d}$, an orientational phase transition of the $\lambda$ type occurs in the nanostructure (Fig. 5), which is associated with surface reconstruction and relaxation processes [36]. There is an opinion that size plays a role in temperature in nanostructures. When $h=d$, in particular, the Hall-Petch law is changed to the opposite [42] and other phenomena.

In order to describe phase transitions in nanostructures, various models have been proposed, among which we can mention the Landau mean field method, in which the order parameter is used [43]. We will use the Landau theory, replacing the temperature $T$ with the coordinate $\mathrm{h}$.

In Landau's theory, the temperature-dependent order parameter is associated with crystal symmetry. In this case, in one of the phases (as a rule, in the high-temperature phase), the system is not ordered and $\eta=0$. In the ordered phase (usually low-temperature) $\eta \neq 0$.

According to Landau, the thermodynamic potential of the system is expanded in a row in the parameter $\eta$ :

$$
F(h, \eta)=F_{0}(h)+A \eta+B \eta^{2}+C \eta^{3}+D \eta^{4}+E \eta^{5}+\cdots,
$$

where $\mathrm{F}_{0}(\mathrm{~h})(\mathrm{T}=\mathrm{h})$ is the part of the free energy independent of $\eta$, and the coefficients $A, B, \ldots$ may depend on $\mathrm{h}$. From the condition of thermodynamic equilibrium of the existence of a phase, there should be a minimum of its free energy, at which $\partial \mathrm{F} / \partial \eta=0$. From here it is obvious that the coefficient for the first degree should be zero: $\partial \mathrm{F} / \partial \eta=A=0$ (all subsequent terms of the decomposition $\partial \mathrm{F} / \partial \eta$ are equal to zero, since in the unordered phase $\eta=0$ ). In addition, in most cases, the disordered (high-temperature) phase is centrosymmetric, so that the minimum $F(\eta)$ in the vicinity of $\eta=0$ should be symmetric. Therefore, the decomposition $\partial^{2} \mathrm{~F} / \partial^{2} \eta$ must be characterized by an even series (polynomial). For this reason, all coefficients with odd powers $\eta$ in expression (10) must vanish. This gives grounds to rewrite the expression for the thermodynamic potential in the following form:

$$
F(h, \eta)=F_{0}(h)+(1 / 2 \alpha) \eta^{2}+(1 / 4 \beta) \eta^{4}+(1 / 6 \gamma) \eta^{6}+\cdots,
$$

where $\alpha, \beta$ and $\gamma$ - are the coefficients of the decomposition of the thermodynamic potential with respect to the order parameter: $F(\eta)$. For them, new notation is used - instead of $B, D, \ldots$, and the coefficients $1 / 2,1 / 4, \ldots$ are introduced only in order to simplify the expressions obtained by differentiating the thermodynamic potential. When analyzing the expansion (11), we can conclude that the dependence of the coefficient $\alpha$ on $h$ is sharp (critical). The dependence of $\beta$ and $\gamma$ on $\mathrm{h}$ is not critical, so that it can be neglected. 
By expanding the dependence $\alpha(\mathrm{h})$ in a series in a small (in the vicinity of the transition) parameter (h- $\theta)$ and limiting ourselves to the first member of this series, we have:

$$
\alpha=\alpha_{0}(h-\theta),
$$

where $\alpha_{0}$ is a coefficient independent of $h$.

In Landau's theory, the character of the FP (features of the second kind or the first kind) is determined by the sign of the coefficient of the fourth power of the order parameter: $\eta^{4}$. In the case of $\beta>0$, we have a second-order phase transition, and in this case, taking the coefficient at $\eta^{6}$ (and at higher degrees of the order parameter) becomes unnecessary, since the stability of the system is already provided by the condition of a positive value of the parameter. Thus, for the thermodynamic description of the FP2 in the centrosymmetric disordered phase, the expansion of $\Phi(\mathrm{h}, \eta)$ in the order parameter takes the form of a finite polynomial:

$$
F(h, \eta)=F_{0}(h)+(1 / 2 \alpha) \eta^{2}+(1 / 4 \beta) \eta^{4},
$$

where $\alpha=\alpha_{0}(\mathrm{~h}-\theta)$ and $\beta>0$.

The specific form of the function (13) depends on the physical meaning of the order parameter.

According to microscopic changes in the structure, phase transitions are divided into displacement type and order-disorder type transitions.

The order parameter for order-disorder phase transitions is described as follows. A change in the symmetry of a crystal can occur as a result of the redistribution of the probability that atoms are located at different equilibrium positions in the unit cell. Suppose that there are two such positions and they are "populated» respectively with a concentration of $\mathrm{N}_{1}$ and $\mathrm{N}_{2}$ atoms - the number of atoms located respectively in positions 1 and 2 . At sufficiently high temperatures, these positions are uniformly populated, the probability of finding an atom in each of them is the same: $N_{1}=N_{2}$. Since on average (for example, on average over time) the internal atom is in the center of the cell, the symmetry of the structure does not change. The phase transition into an ordered phase with decreasing temperature manifests itself as the appearance of the difference in the probabilities of finding a particle in different positions, that is, the difference in the number of particles in these positions. At the phase transition point, the value becomes nonzero:

$$
\eta=\left(N_{1}-N_{2}\right) /\left(N_{1}+N_{2}\right) \text {. }
$$

Structural phase transitions in which symmetry changes occur as a result of the redistribution of particles over previously equally probable positions are called order-disorder transitions.

In order for the phase transition point to correspond to a steady state, the thermodynamic potential must have a minimum at this point:

$$
\begin{aligned}
& \frac{\partial F}{\partial \eta}=2 A_{0} \eta+4 C_{0} \eta^{3}=0 \\
& \frac{\partial^{2} F}{\partial \eta^{2}}=2 A_{0}+12 C_{0} \eta^{2}>0 .
\end{aligned}
$$

From (15) it follows that:

$$
\begin{array}{ll}
h>d & \eta=0 \quad A_{0}>0 ; \\
h<d & \eta=\sqrt{-\frac{A_{0}}{2 C_{0}}} .
\end{array}
$$

The second postulate of the Landau theory is a linear dependence on $\mathrm{h}$ of the coefficient $\mathrm{A}_{0}$ near the transition under the condition of constant pressure:

$$
A_{0}(h)=\alpha_{0}(h-d)
$$

where $\alpha_{0}=\left(\partial \mathrm{A}_{0} / \partial \mathrm{h}\right)_{\mathrm{h}=\mathrm{d}}-$ const.

It is assumed that $\mathrm{C}_{0}$ does not depend on $\mathrm{h}$. Thus, the value of the order parameter $\eta$ for $h<d$ is:

$$
\eta=\sqrt{\frac{\alpha_{0}(d-h)}{2 C_{0}} .}
$$

Entropy near the phase transition point:

$$
S=-\frac{\partial F}{\partial h}=-S_{0}-\frac{\partial A_{0}}{\partial h} \cdot \eta^{2}
$$


In the symmetric high-temperature phase, $\eta=0, S=S_{0}$; with $h<d$ :

$$
S=S_{0}+\frac{A_{0}}{2 C_{0}} \frac{\partial A_{0}}{\partial h}=S_{0}+\frac{\alpha_{0}^{2}}{2 C_{0}}(h-d) .
$$

Note that the resulting function $S(h)$ is continuous. Now you can find the values of heat capacity $C_{p}=h\left(\frac{\partial S}{\partial h}\right)_{p}$ in both phases with $h=d$. In the low-temperature phase $C_{p}=C_{p_{0}}+\frac{\alpha_{0}^{2} d}{2 C_{0}}$, in the hightemperature phase $C_{p}=C_{p_{0}}$, where $C_{p_{0}}=h \frac{\partial S_{0}}{\partial h}$. Heat capacity jump during phase transition:

$$
\Delta C_{p}=\frac{\alpha_{0}^{2} \cdot d}{2 C_{0}}
$$

From Table and Figure 3 it follows that $\Delta \mathrm{C}_{\mathrm{p}}=0.5 \mathrm{~d}=1.15(\mathrm{~J} / \mathrm{mol} \cdot \mathrm{K})$. In [44], the molecular dynamics calculations of the heat capacity of gold with particle sizes from 1.5 to $5.5 \mathrm{~nm}$ were performed (Fig. 6). From Figure 6 that $\Delta \mathrm{C}_{\mathrm{p}} \approx 1.65(\mathrm{~J} / \mathrm{mol} \cdot \mathrm{K})$, which is close to that obtained by us, given the proximity of computer calculations.

The lattice parameter of gold is a $=0.4 \mathrm{~nm}$. So the $\mathrm{d}(\mathrm{I})$ layer contains about 3 monolayers of atoms of gold and d(II) - about 60 monolayers of gold.

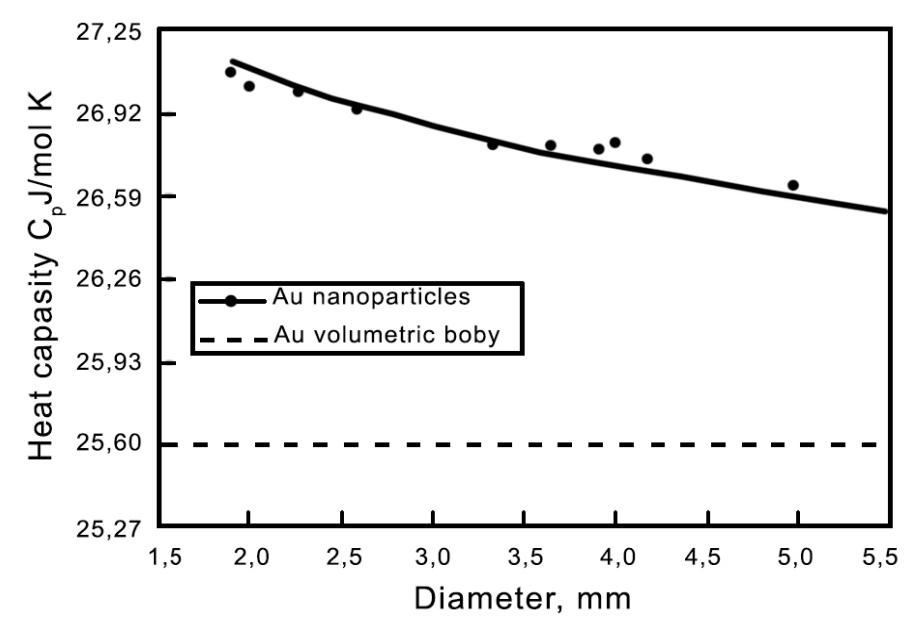

Figure 6. Gold Heat Capacity [44]

The above results can give a significant impetus to the research of atomically smooth metals and other compounds.

The work was performed under the program of the MES RK Grants No.0118PK000063 and No. $\Phi .0780$.

\section{References}

1 Wolf E.L. Nanophysics and Nanotechnology: An Introduction to Modern Concepts in Nanoscience / E.L. Wolf. - WileyVCH: Weinheim, Germany, 2004. - 174 p.

2 Dupas C. Nanoscience: Nanotechnologies and Nanophysics / C. Dupas, P. Houdy, M. Lahmani (Eds.). - Springer-BerlinHeidelberg-New York, 2007. - 823 p.

3 Sattler K.D. Handbook of Nanophysics: Nanoelectronics and Nanophotonics / K.D. Sattler. — CRC Press, 2011. — 780 p.

4 Raz J. Nanoparticles / J. Raz. — Berlin; Boston: Walter de Gruyter GmbH \& Co., KG, 2015. — 283 p.

5 Rogers B. Nanotechnology: understanding small systems / B. Rogers, J. Adams, S. Pennathur. — Boca Raton: CRC Press, Taylor\&Francis Group, 2015. - 407 p.

6 Encyclopedia of nanotechnology / Bharat Bhushan, editor. — Dordrecht: Springer, 2016. — $946 \mathrm{p}$ 
7 Biomedical nanomaterials: from design to implementation / edited by Thomas J. Webster and Hilal Yazici. — London, England: The Institution of Engineering and Technology, 2016. - $337 \mathrm{p}$.

8 Ngô Ch. Our nanotechnology future / Ch. Ngô, J.B. Natowitz. - Chicago: University of Chicago Press, 2017. — 243 p.

9 Mokkapati S. Nanowires for energy applications / S. Mokkapati, Ch. Jagadish. — Cambridge, MA: Academic Press, 2018. $-536 \mathrm{p}$.

10 Roy S. Nanotechnology: synthesis to applications / S. Roy, Ch.K. Ghosh \& Ch.K. Sarkar. - Boca Raton, FL: CRC Press, Taylor \& Francis Group, 2018. - 328 p.

11 Prutton M. Introduction to surface physics / M. Prutton. — Clarendon Press, $1994-196$ p.

12 Starzynski G. Natural surface layer of metals / G. Starzynski \& W. Gambin // Acta Physica Polonica. — 1996. — Vol. 89, No. 3. - P. 377-381.

13 Davis J.R. Surface Engineering for Corrosion and Wear Resistance / J.R. Davis. — ASM International, 2001. — 279 p.

14 Davim J.P. Materials and Surface Engineering / J.P. Davim. — Woodhead Publishing, 2012. — 308 p.

15 Dearnley P.A. Introduction to Surface Engineering / P.A. Dearnley. - Cambridge University Press, 2017. — 314 p.

16 Venables J.A. Introduction to Surface and Thin Film Processes / J.A. Venables. — Cambridge University Press, 2003. $293 \mathrm{p}$.

17 Desjonqueres M.-C. Concepts in Surface Physics / M.-C. Desjonqueres, D. Spanjaard. — Springer Science \& Business Media, 2012. $-607 \mathrm{p}$.

18 Mamonova M.V. Surface Physics: Theoretical Models and Experimenal Methods / M.V. Mamonova, V.V. Prudnikov, I.A. Prudnikova. - CRC Press, 2016. - 384 p.

19 Hoffman D.M. Handbook of vacuum Science and Thechnology / D.M. Hoffman, B. Singh, J.H. Thomas. — Academic Press, 1998. $-836 \mathrm{p}$.

20 Baird D. Probing the History of Scanning Tunneling Microscopy / D. Baird, A. Shew. — Amsterdam: IOS Press, 2004. P. $145-156$

21 Paul W. Atomically defined tips in scanning probe microscopy/ W. Paul. — Montreal, Québec, Canada, 2013. — 284 p.

22 Chen C.J. Introduction to Scanning Tunneling Microscopy / C.J. Chen. — Oxford University Press, 2015. - 488 p.

23 Logeeswaran V.J. Ultra-smooth metal surfaces generated by pressure-induced surface deformation of thin metal films / V.J. Logeeswaran, M.-L. Chan, Y. Bayam // Appl. Phys. A — Materials Science \& Processing, 2007. - 6 p.

24 Barquist C.S. Low temperature transport measurements on atomically smooth metallic and oxygen deficient strontium titanate / C.S. Barquist, I.H. Kwak, J. Bauer, T. Edmonds, A. Biswas, Y. Lee // Journal of Physics: Conference Series. - 2014. - 568. -052004 .

25 Kho K.W. Sub-micron free-standing metal slabs with dielectric nano-voids of arbitrary shapes embedded beneath atomicallyflat surface / K.W. Kho, Z.X. Shen, M. Olivo // Optical Society of America. — 2011. — Vol. 19, No. 11. — P. 10518-10534.

26 Bittner A.M. Clusters on soft matter surfaces / A.M. Bittner // Surface Science Reports. — 2006. — Vol. 61. — P. $383-428$.

27 Quan J.J. Atomic assembly of metal surfaces and interfaces / J.J. Quan, X.W. Zhou, H.N.G. Wadley // Surface Science. 2006. - Vol. 600. - P. 4537-4547.

28 Leandro L. Ultrathin, Ultrasmooth Gold Layer on Dielectrics without the Use of Additional Metallic Adhesion Layers / L. Leandro, R. Malureanu, N. Rozlosnik, A. Lavrinenko // A C S Applied Materials and Interfaces. — 2015. — 7(10). — P. 57975802 .

29 Ivchenko V.A. Development of Amorphized States in Subsurface Metal Regions under Radiation Exposure / V.A. Ivchenko // Technical Physics Letters. - 2013. - Vol. 39. - No. 4. - P. 357-359.

30 Folsch S. From atomic kinks to mesoscopic surface patterns: Ionic layers on vicinal metal surfaces / S. Folsch, A. Riemann, J. Repp, G. Meyer \& K.H. Rieder // Phys. Rev. B. — 2002. — Vol. 66. — P. 161409-1 - 161409-4.

31 Chen S.-W. ITO-Ag alloy-ITO film with stable and high conductivity depending on the control of atomically flat interface / S.-W. Chen, C.-H. Koo // Materials Letters. — 2007. — Vol. 61. — P. 4097-4099.

32 Tamm I.E. Uber eine mogliche Art der Elektronenbildung an Kristalloberflachen / I.E. Tamm // Z. Phys. — 1932. — Bd. 76. - S. 849-854. 759.

33 Shockley W. Electronic energy bands in sodium chloride / W. Shockley // Physical Review. — 1936. — Vol. 50. — P. 754-

34 Pedersen K. Quantum size effects in nanostructures / K. Pedersen. - Aalborg University, 2006. - 33 p.

35 Pashkovskii A.B. Electron passage through quantum-size structures in high-frequency fields / A.B. Pashkovskii // JETP, 1996. - 82 (5). - 1779-1805.

36 Aghemenl Oh. E. Surface relaxation and surface energy of face -centered Cubic metals / Oh.E. Aghemenl , S.E. Iyayi, G.O. Avwir // J. Appl. Sci. Environ. Mgt. — 2006. — Vol. 10 (1). — P. 37-42.

37 Patra C.N. Electric double layer at a metal/electrolyte interface: A density functional approach / C.N. Patra, S.K. Ghosh // J. Chem. Phys. - 1995. - Vol. 102. - P. 2556-2566.

$38 \mathrm{Lu} \mathrm{H}$. Electron work function-a promising guiding parameter for material design / H. Lu, Z. Liu, X. Yan, D. Li, L. Parent, H. Tian // Scientific Reports. - 2016. — Vol. 6. - P. 24366-24372.

39 Юров В.М. Поверхностное натяжение твердых тел / В.М. Юров // Вестн. Караганд. ун-та. Сер. Физика. — 2007. № 1(45). - C. 23-29.

40 Yurov V.M. Superfecial tension of pure metals / V.M. Yurov // Eurasian Physical Technical Journal. — 2011. — Vol. 8. — № 1(15). - P. 10-14.

41 Guo J. X-Rays in Nanoscience: Spectroscopy, Spectromicroscopy, and Scattering Techniques / J. Guo. - WILEY-VCH, Verlag, 2010. - $263 \mathrm{p}$. 
42 Юров В.М. Механическая прочность металлических наноструктур / В.М. Юров // Вестн. Караганд. ун-та. Сер. Физика. - 2013. - № 3 (71). - С. 56-61.

43 Maritan A. Derivation of Landau theories and lattice mean-field theories for surface and wetting phenomena from semiinfinite ising models / A. Maritan, G. Langie \& J.O. Indekeu // Physica A. — 1991. — Vol. 170. — P. 326-354.

44 Гафнер Ю.Я. Анализ теплоемкости нанокластеров ГЦК-металлов на примере $\mathrm{Al}, \mathrm{Ni}, \mathrm{Cu}, \mathrm{Pd}, \mathrm{Au} /$ Ю.Я. Гафнер, С.Л. Гафнер, И.С. Замулин, Л.В. Редель, В.С. Байдышев // Физика металлов и металловедение. — 2015. — Т. 116. — № 6. C. 602-609.

\author{
В.М. Юров, С.А. Гученко, В.Ч. Лауринас, О.Н. Завацкая
}

\title{
Металдардың беткі қабатындағы құрылымдық фазалық өту
}

\begin{abstract}
Мақалада таза металдардың бетіндегі түрлі құбылыстарға шолу ұсынылған: Тамм және Шоклидің беттік күйлерінің пайда болуы; кванттық өлшем эффектілері; электрлі қос қабат, металдан электрондардың шығу жұмысы. Қазіргі тұжырымдамаларға сәйкес, беттік қабат - көлем мен термодинамикалық тепе-теңдікте болатын өте жұқа фаза. Металдардың беткі қабатының жаңа моделі ұсынылған. Беткі қабаттағы құрылымдық фазаға өтуге баса назар аударылады. Бұл мәселені біз алғаш рет көтеріп отырмыз. Наноқұрылымдардағы фазалық өтулерді сипаттау үшін әртүрлі модельдер ұсынылды, олардың ішінде реттілік параметрін қолданатын Ландаудың орташа өріс әдісін атап өтуге болады. Ландау теориясын пайдаланып, $\mathrm{T}$ температурасын $\mathrm{h}$ координатпен ауыстырамыз. Эксперимент көрсеткендей, жылусыйымдылығының секірісі $\quad \Delta \mathrm{C}_{\mathrm{p}}=0, \mathrm{~d}=1,15 \quad$ (Дж/моль $\cdot$ К). Жүргізілген молекулалық динамикалық есептеулер бөлшектердің өлшемдері 1,5-тен 5,5 нм дейінгі алтынның жылусыйымдылығы $\Delta \mathrm{C}_{\mathrm{p}} \approx 1,65$ (Дж/моль $\cdot$ ) болатынын көрсетті. Алтынның тор параметрі $\mathrm{a}=0,4$ нм құрайды. Демек, D (I) қабаты алтын атомдарының 3 моноқабатынан және D (II) - алтынның 6 моноқабатынан тұрады.
\end{abstract}

Кілт сөздер: беткі қабат, наноқұрылым, фазалық өту, Ландау теориясы, жылу сыйымдылығы.

\author{
В.М. Юров, С.А. Гученко, В.Ч. Лауринас, О.Н. Завацкая
}

\section{Структурный фазовый переход в поверхностном слое металлов}

\begin{abstract}
В статье дан обзор различных явлений на поверхности чистых металлов: возникновение поверхностных состояний Тамма и Шокли; квантово-размерные эффекты; двойной электрический слой, работа выхода электронов из металла. Согласно современным представлениям поверхностный слой представляет собой очень тонкую фазу, находящуюся в термодинамическом равновесии с объемом. Предложена новая модель поверхностного слоя металлов. Основное внимание уделено структурному фазовому переходу в поверхностном слое. Этот вопрос поднимается нами впервые. Для описания фазовых переходов в наноструктурах предложены различные модели, среди которых можно отметить метод среднего поля Ландау, в котором используется параметр порядка. Мы воспользуемся теорией Ландау, заменяя температуру T на координату $\mathrm{h}$. Экспериментально показано, что скачок теплоемкости $\Delta \mathrm{C}_{\mathrm{p}}=0, \mathrm{~d}$ $=1,15$ (Дж/моль $\cdot$ К). Проведенные расчеты методом молекулярной динамики теплоемкости золота при размерах частиц от 1,5 до 5,5 нм показали, что $\Delta \mathrm{C}_{\mathrm{p}} \approx 1,65$ (Дж/моль $\cdot$ К). Это близко к полученному нами результату, учитывая приближенность компьютерных расчетов. Параметр решетки золота $\mathrm{a}=0,4$ нм. Значит, слой d (I) содержит около 3 монослоев атомов золота и d (II) - около 6 монослоев золота.
\end{abstract}

Ключевые слова: поверхностный слой, наноструктура, фазовый переход, теория Ландау, теплоемкость.

\section{References}

1 Wolf, E.L. (2004). Nanophysics and Nanotechnology: An Introduction to Modern Concepts in Nanoscience. Wiley-VCH: Weinheim, Germany.

2 Dupas, C., Houdy, P., \& Lahmani, M. (Eds.) (2007). Nanoscience: Nanotechnologies and Nanophysics. Springer-BerlinHeidelberg-New York. -823 p.

3 Sattler, K.D. (2011). Handbook of Nanophysics: Nanoelectronics and Nanophotonics. CRC Press.

4 Raz, J. Nanoparticles (2015). Berlin; Boston: Walter de Gruyter GmbH \& Co., KG.

5 Rogers, B., Adams J., \& Pennathur, S. (2015). Nanotechnology: understanding small systems. Boca Raton: CRC Press, Taylor\&Francis Group.

6 Encyclopedia of nanotechnology / Bharat Bhushan, editor. (2016). Dordrecht: Springer.

7 Thomas, J. Webster \& Hilal, Yazici. (Eds.). (2016). Biomedical nanomaterials: from design to implementation. London, England: The Institution of Engineering and Technology. 
8 Ngô, Ch., \& Natowitz, J.B. (2017). Our nanotechnology future. Chicago: University of Chicago Press.

9 Mokkapati, S., \& Jagadish, Ch. (2018). Nanowires for energy applications. Cambridge, MA: Academic Press.

10 Roy, S., Ghosh, Ch.K., \& Sarkar, Ch.K. (2018). Nanotechnology: synthesis to applications. Boca Raton, FL: CRC Press, Taylor\&Francis Group.

11 Prutton, M. (1994). Introduction to surface physics. Clarendon Press.

12 Starzynski, G., \& Gambin, W. (1996). Natural surface layer of metals. Acta Physica Polonica, Vol. 89, No. 3, $377-381$.

13 Davis, J.R. (2001). Surface Engineering for Corrosion and Wear Resistance. ASM International.

14 Davim, J.P. (2012). Materials and Surface Engineering. Woodhead Publishing.

15 Dearnley, P.A. (2017). Introduction to Surface Engineering. Cambridge: Cambridge University Press.

16 Venables, J.A. (2003). Introduction to Surface and Thin Film Processes. Cambridge: Cambridge University Press.

17 Desjonqueres, M.-C., \& Spanjaard, D. (2012). Concepts in Surface Physics. Springer Science \& Business Media.

18 Mamonova, M.V., Prudnikov, V.V., \& Prudnikova, I.A. (2016). Surface Physics: Theoretical Models and Experimenal Methods. CRC Press.

19 Hoffman, D.M., Singh, B., \& Thomas, J.H. (1998). Handbook of vacuum Science and Thechnology. Academic Press.

20 Baird, D., \& Shew, A. (2004). Probing the History of Scanning Tunneling Microscopy. Amsterdam: IOS Press.

21 Paul, W. (2013). Atomically defined tips in scanning probe microscopy. Montreal, Québec, Canada.

22 Chen, C.J. (2015). Introduction to Scanning Tunneling Microscopy. Oxford: Oxford University Press.

23 Logeeswaran, V.J., Chan, M.-L., \& Bayam, Y. (2007). Ultra-smooth metal surfaces generated by pressure-induced surface deformation of thin metal films. Appl. Phys. A-Materials Science \& Processing, 6.

24 Barquist, C.S., Kwak, I.H., Bauer, J., Edmonds, T., Biswas, A., \& Lee, Y. (2014). Low temperature transport measurements on atomically smooth metallic and oxygen deficient strontium titanate. Journal of Physics: Conference Series, 568, 052004.

25 Kho, K.W., Shen Z.X., \& Olivo M. (2011). Sub-micron free-standing metal slabs with dielectric nano-voids of arbitrary shapes embedded beneath atomically-flat surface. Optical Society of America, Vol. 19, No. 11, 10518-10534.

26 Bittner, A.M. (2006). Clusters on soft matter surfaces. Surface Science Reports, Vol. 61, 383-428.

27 Quan, J.J., Zhou, X.W., \& Wadley, H.N.G. (2006). Atomic assembly of metal surfaces and interfaces. Surface Science, Vol. 600, 4537-4547.

28 Leandro, L., Malureanu, R., Rozlosnik, N., \& Lavrinenko, A. (2015). Ultrathin, Ultrasmooth Gold Layer on Dielectrics without the Use of Additional Metallic Adhesion Layers. A C S Applied Materials and Interfaces, 7(10), 5797-5802.

29 Ivchenko, V.A. (2013). Development of Amorphized States in Subsurface Metal Regions under Radiation Exposure. Technical Physics Letters, Vol. 39, No. 4, 357-359.

30 Folsch, S., Riemann, A., Repp, J., Meyer G., \& Rieder, K.H. (2002). From atomic kinks to mesoscopic surface patterns: Ionic layers on vicinal metal surfaces. Phys. Rev. B, Vol. 66, 161409-1-161409-4.

31 Chen, S.-W., \& Koo, C.-H. (2007). ITO-Ag alloy-ITO film with stable and high conductivity depending on the control of atomically flat interface. Materials Letters, Vol. 61, 4097-4099.

32 Tamm, I.E. (1932). Uber eine mogliche Art der Elektronenbildung an Kristalloberflachen [About a possible way of electron formation on crystal surfaces]. Z. Phys., Bd. 76, 849-854 [in German].

33 Shockley, W. (1936). Electronic energy in sodium chloride. Physical Review, Vol. 50, 754-759.

34 Pedersen, K. (2006). Quantum size effects in nanostructures. Aalborg University.

35 Pashkovskii, A.B. (1996). Electron passage through quantum-size structures in high-frequency fields. JETP, 82 (5), $1779-1805$.

36 Aghemenl, Oh.E., Iyayi, S.E., \& Avwir, G.O. (2006). Surface relaxation and surface energy of face -centered Cubic metals. J. Appl. Sci. Environ. Mgt., Vol. 10 (1), 37-42.

37 Patra, C.N., \& Ghosh, S.K. (1995). Electric double layer at a metal/electrolyte interface: A density functional approach. J. Chem. Phys., Vol. 102, 2556-2566.

38 Lu, H., Liu, Z., Yan, X., Li, D., Parent, L., \& Tian, H. (2016). Electron work function-a promising guiding parameter for material design. Scientific Reports, Vol. 6, 24366-24372.

39 Yurov, V.M. (2007). Poverkhnostnoe natiazhenie tverdykh tel [Surface tension of solids]. Vestnik Karahandinskoho universiteta. Seriia Fizika, 1 (45), 23-29 [in Russian].

40 Yurov, V.M. (2011). Superfecial tension of pure metals. Eurasian Physical Technical Journal, Vol. 8, 1(15), 10-14.

41 Guo, J. (2010). X-Rays in Nanoscience: Spectroscopy, Spectromicroscopy, and Scattering Techniques. WILEY-VCH, Verlag.

42 Yurov, V.M. (2013). Mekhanicheskaia prochnost metallicheskikh nanostruktur [Mechanical strength of metallic nanostructures]. Vestnik Karahandinskoho universiteta. Seriia Fizika, 3 (71), 56-61 [in Russian].

43 Maritan, A., Langie, G., Indekeu, J.O. (1991). Derivation of Landau theories and lattice mean-field theories for surface and wetting phenomena from semiinfinite ising models. Physica A, Vol. 170, 326-354.

44 Gafner, Iý.Ia., Gafner, S.L., Zamýlın, I.S., Redel, L.V., Ba1dyshev, V.S. (2015). Analiz teploemkosti nanoklasterov HTsKmetallov na primere $\mathrm{Al}, \mathrm{Ni}, \mathrm{Cu}, \mathrm{Pd}$, $\mathrm{Au}$ [Analysis of heat capacity of fcc-metal nanoclusters by the example of $\mathrm{Al}, \mathrm{Ni}, \mathrm{Cu}, \mathrm{Pd}, \mathrm{Au}$. Fizika metallov i metallovedenie, Vol. 116, 6, 602, 603 [in Russian]. 